\title{
Effects of Chlorocholine Chloride (CCC) on Plant Height and Inulin Content in Jerusalem Artichoke (Helianthus tuberosus L.)
}

\author{
Mikołaj WAWRZYNIAK ${ }^{1 *}$, Artur SZWENGIEL ${ }^{2}$, Marta STELMACH-MARDACH ${ }^{3}$ and Roman \\ HOŁUBOWICZ ${ }^{1}$ \\ ${ }^{1}$ Department of Plant Pathology, Seed Science and Technology. University of Life Science, Poznań, \\ Poland \\ ${ }^{2}$ Department of Food Science and Nutrition. University of Life Science Poznan, Poland \\ ${ }^{3}$ Institute of Human Nutrition Potsdam-Rehbruecke, Department of Epidemiology, Germany \\ *)Corresponding author, e-mail: mikwawrz@gmail.com
}

BulletinUASVM Horticulture 73(2) / 2016

Print ISSN 1843-5254, Electronic ISSN 1843-5394

DOI:10.15835/buasvmcn-hort:11957

\begin{abstract}
Jerusalem artichoke (Helianthus tuberosus L.) is a herbaceous perennial plant rich in inulin and useful source of biomass. Due to its low agricultural requirements and high adaptability, it can provide a high amount of biomass yield even on low quality sites. The plant is used in food industry, bio-fuel production, forage, pharmacy and nutrition. Its tubers accumulate approx. $10-20 \%$ of inulin in fresh weight. Currently, the use of Helianthius tuberosus $L$. as a potential dietary strategy in patients affected by type 2 Diabetes is a real challenge. Moreover, deep understanding of the relationship between diet and composition of gut microbiota can bring the new insight in the treatment of inflammatory-dependent diseases. The main aim of this study was to examine the effects on plant growth of retardant Chlorocholine Chloride (CCC) -on the plants' height of $H$. tuberosus- and inulin content in the tubers. The plant material (528 tubers) for the experiment was bought from a Polish commercial company and planted in field in the middle of April 2014. After planting, half of them were sprayed with $0.75 \%$ retardant of CCC. Furthermore, in every week for 12 weeks, the plants' heights were measured. At the end of the vegetation period, 6 tubers from each treatment were dug out and chemically analyzed for inulin content using High Pressure Size Exclusion Chromatography.

After the first week of CCC use, 16\% decrease of the plant's heights was observed. The heights of the plants sprayed with CCC were significantly different comparing to Control plants. Week after week the plant growth was significantly slower in plants sprayed with CCC already after the first three weeks of applying retardant. Differences in plants height sustain to the end of measurements. Used retardant and its concentration did not affect the inulin content of the tubers.
\end{abstract}

Keywords: Chlorocholine Chloride (CCC), Jerusalem artichoke, inulin

\section{INTRODUCTION}

Jerusalem artichoke (Helianthus tuberosus L.), is a herbaceous perennial plant from the Asteraceae family native to temperate regions of North America, from northern parts of Canada to Florida. It has been brought to Europe by a French explorer Champlain in 1605 being widely used in cuisine in that time (Cosgrove et al., 1991). It is a plant that reaches $3 \mathrm{~m}$ height and produces elongated, brown tubers very rich in inulin. Beside the chicory plant (Cichorium intybus L.) it is considered as a main crop in inulin production and used as a source of dietary fiber in food production (Xiao et al., 2011; Gunnarsson et al. 2014). 
Over the recent years, Jerusalem artichoke has been gaining the attention of more and more consumers due to its low agricultural requirements and wide range of application: as forage plant, in food industry, in biomass production, pharmacy, nutrition and medicine. Jerusalem artichoke is characterized by a specific adaptability to changing climate conditions; e.g. drought stress tolerance, frost, salt, pest, diseases and low soil requirements (Xiao et al., 2011). The plant requires an annual precipitation from 31 to $282 \mathrm{~mm}$ and an average day temperature within the range of 6.3$26.6^{\circ} \mathrm{C}$ and a minimum of 125 days without frost per year. It grows well in different types of soil, at various soil $\mathrm{pH}$ ranging from 4.5 to 8.2. Jerusalem artichoke can grow also in fields irrigated with sea water (Zhao et al., 2008). Its tubers are relatively fragile, so it is recommended to grow them on lighter, sandy soils with good drainage, to prevent them from damage during harvest (Cosgrove et al., 1991; Xiao et al., 2011). The cultivation of the plant is recommended in dry areas with poor soils, on which it yields much better than other crops, e.g. potatoes. According to the results obtained by Matias et al. (2013) in Jerusalem artichoke crop production, NPK fertilization did not affect plant growth, but it did affect the increase of total sugars in the plant. The recommended NPK doses of fertilizers in the paper were 54-108-162 $\mathrm{kg} \mathrm{ha}^{-1}$. In order to achieve high crop yield, a much more important factor that has to be taken into account is the selection of the appropriate term of harvest and weather conditions during the harvest. The recorded yield per hectare in the experiment was more than 40 Tonnes of tubers (Gunnarsson et al., 2014).

Fresh Jerusalem artichoke tubers contain 75$80 \%$ water, $2-3 \%$ protein and $15-16 \%$ carbohydrate, of which around $80 \%$ is inulin. Tubers of this species are very similar to the potato tubers. The only difference between them is that the $80 \%$ of carbohydrates contained in potato tubers is starch instead of inulin. Jerusalem artichokes can also be used as plant feed for cattle (Xiao et al., 2011). It constitutes the raw material for the production of: ethanol, acotono-butanol, 2,3-butanediol, sorbitol and other compounds (Cosgrove et al., 1991, D'Egidio et al., 1996). Jerusalem artichoke is a species very useful for the production of bio-ethanol, due to the high content of inulin and fructans (Xiao et al., 2011). According to Duke (1983), bio-etha- nol from artichoke has a better quality than the one obtained from sugar beet. Gunnarsson et al. (2014) reported that the tubers of Jerusalem artichoke can produce from 3,060 to $11,000 \mathrm{l} / \mathrm{ha}$, an amount which is almost twice more than from 1 ha of sugar cane $(6,471 \mathrm{l})$ and almost triple than obtained from 1 ha of maize $(4,182 \mathrm{l})$.

The extracts obtained from Jerusalem artichoke showed strong antiseptic and anti-fungal properties. Ahmed et al. (2005) showed that has an inhibition capacity of the in vitro cancerous cells. Jerusalem artichoke has laxative, stimulant, bile, diuretic, spermatogenic and toning properties and has been used by many cultures as a medicinal herb (Xiao et al., 2011). It is also recommended for people on special diets, e.g. for diabetics.

Inulin is a heterogeneous collection of fructose polymers. In food industry it is used as a replacement for fats and sugars or soluble fiber. It is also widely used in the pharmaceutics, as an adjunct, stabilizer, as well as used in medical diagnostics in the study of kidney function. It can also be used in pharmacology as a drug carrier and a stabilizer for protein drugs and vaccines. It is an activator for certain metabolic pathways, exhibiting anticancer activity and stabilizing the immune system (Barclay et al., 2010). Inulin used in the human diet has many beneficial effects: it increases the absorption of calcium and magnesium ions, and also bone mineralization in young people. It may also reduce the risk of heart attack, by controlling the levels of cholesterol and blood glucose. Furthermore, inulin may regulate the immune system, improving the effectiveness of vaccines (Barclay et al., 2010). Inulin is a natural pre-biotic. Pre-biotics are compounds supporting the development and growth of the natural flora of the digestive system, unlike pro-biotics, which are selected strains of bacteria. Pre-biotics, in contrast to pro-biotics may be subjected to boiling or baking without the risk of losing its health characteristics (Ramnani et al., 2010).

Chlorocholine chloride (or 2-chloroethyl trimethylammonium, known as CCC or Chloromequat) is one of the best known substances that inhibits growth. Its action is an inhibition of choline metabolism included in lipid composition which effectively stops the growth elongation and increases the intensity of growth in width of the plants. The efficiency of the substance depends on its concentration in the species, the development 

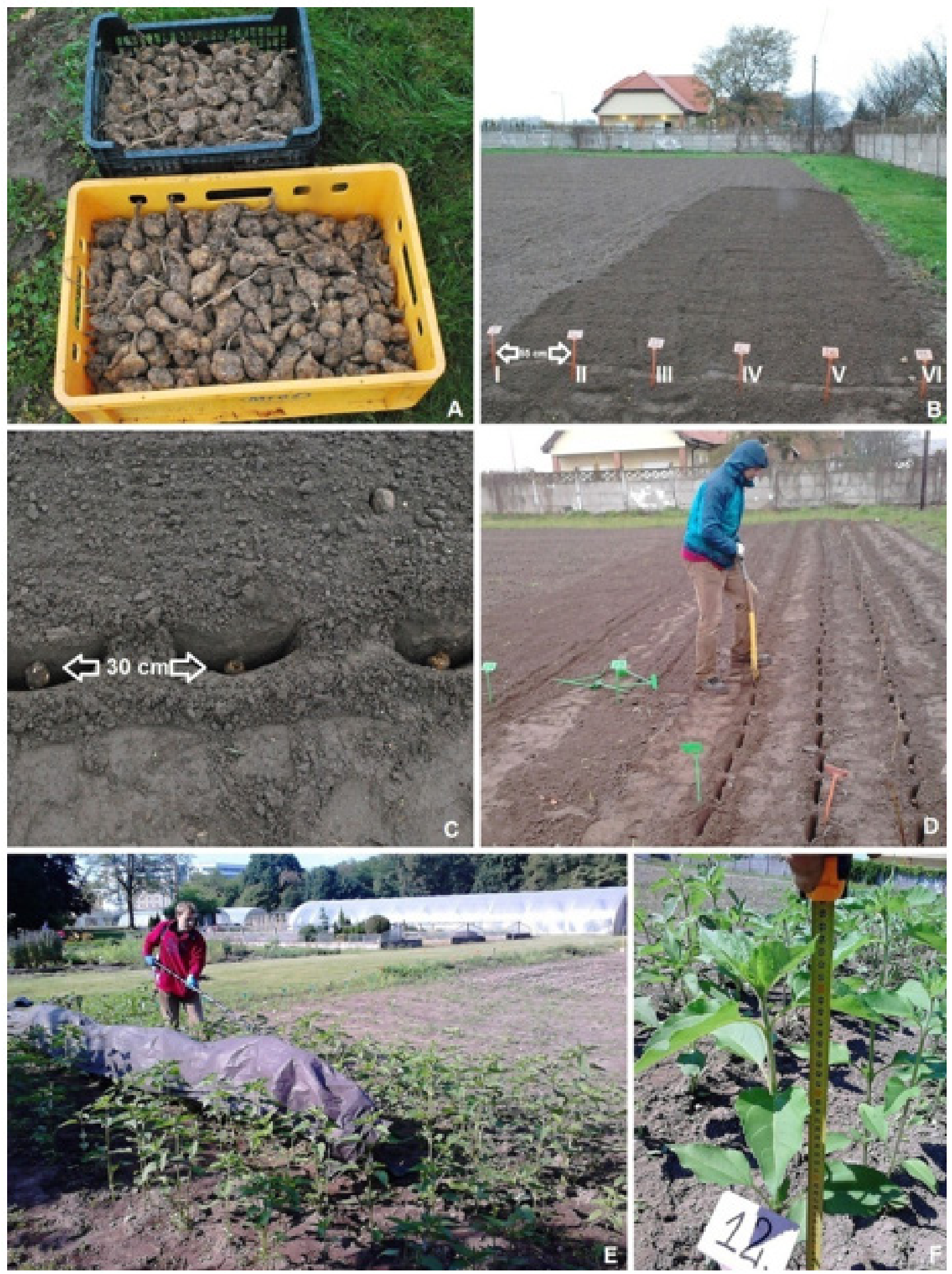

Fig. 1. (A) Plant material; (B) preparation of the experimental plot before planting tubers, setting rows; (C), (D) planting the tubers; (E) spraying rows I-III, with the growth retardant, the plants in the remaining rows covered with foil; (F) the first height measurement 
phase of the plant, the method of application of the substance as well as external conditions. In horticulture CCC is used to stimulate the formation of potato tubers, shoots shortening in pear, rooting of apple seedlings, as well as in the cultivation of tomatoes, beans and some kinds of flowers (Hołubowicz 1998; Radwan et al., 1971).

The aim of this study was to examine the effects of a plant retardant containing CCC on plant growth in Jerusalem artichoke's shoots, and to demonstrate its impact on the inulin content in Jerusalem artichoke's tubers.

\section{MATERIALS AND METHODS}

Plants of Helianthus tuberosum "Albik" that were used for this experiment have been bought from the Service and Trade Company in Sławno (Western Poland). The plant material had a very good quality (Fig. 1 A). Tubers were planted in $14^{\text {th }}$ of April, 2014, in the experimental plot of the Experimental Station Marcelin of the Horticulture and Landscape Architecture Department of the University of Life Sciences in Poznań. Soil analysis did not reveal the need for additional soil fertilization. In the previous year, on the used experimental plot adzuki bean (Vigna angularis W.F. Wight) was grown. In total, 528 tubers were selected and planted in 6 rows, 88 units each. The spacing between tubers was $55 \times 25 \mathrm{~cm}$ (Fig. $1 \mathrm{~B})$. The tubers were planted at a depth of 25 cm (Fig. 1 C, D). In the $7^{\text {th }}$ of June, 2014, when the plants reached the height of about $50 \mathrm{~cm}, 20$ equal plants were selected from each row and their heights were measured. The selected plants were marked with ribbons. All the plants from the first three rows were sprayed with growth retardant containing CCC (trade Polish name 'Antywylegacz') in concentration of $0.75 \%$. The application of the chemicals was performed using a 10 liters handheld sprayer, 'Kwazar'. The working pressure was 2-3 atmospheres. Plants from the rows 4 to 6 were covered with foil and used as Control (Fig. 1 E). Plant height measurements were carried out for 12 weeks, on dates from $7^{\text {th }}$ of June to the $23^{\text {rd }}$ of August, 2014. The measurements have been done in every week in the morning, with a $5 \mathrm{~m}$ measuring tape (Fig. $1 \mathrm{~F}$ ). The plants were measured from the ground level to the apical bud. For each treatment, 3 replications of population of 20 plants were measured.
Jerusalem artichoke tubers for inulin content analysis were collected in November the $4^{\text {th }}, 2014$, after their flowering stage was completed. Using a shovel, tubers were carefully pulled out from the soil. Analyses were done on 10 randomly selected tubers treated with CCC and on another 10 tubers from the covered rows of Control. Average weight of molecular inulin was marked by size exclusion chromatography (SEC). Inulin was extracted from $1 \mathrm{~g}$ shredded pulp samples, dissolved in $10 \mathrm{~g}$ of water, and extracted at a temperature of $85{ }^{\circ} \mathrm{C}$ for 3 hours with gentle stirring. The inulin content analysis technique was performed by High Pressure Size Exclusion Chromatography (HPSEC), using 3 columns for analysis in SEC under water condition (OHpak Shodex SB-800HQ series) and protective column of type SB-G (Showa Denko, Japan). The mobile phase (eluent) was a $0.1 \mathrm{M}$ aqueous solution of sodium nitrate; the flow rate was $0.3 \mathrm{ml} / \mathrm{min}$. The calibration was performed using standard base on pullulan. Inulin was analyzed in $\mathrm{H}_{2} \mathrm{O} / \mathrm{NaNO}_{3}$; the refractive index of the solvent was 1.3340, while the sample 0.149. The calculation of molar mass polidisperse was performed with the OmiSEC 4.7. Software Malvern, TX, United States (Gaafar et al., 2010).

The 10.0 STAT Software was used for the statistical analysis. The level of significance was set at $\mathrm{p}=0.05$.

\section{RESULTS AND DISCUSSION}

Growth retardants used in horticulture and agriculture are intended to reduce the elongation growth of plants, without reducing their productivity (Rademacher, 2000).

Despite the fact that Helianthus tuberosum species was relatively unknown, due to its low growing conditions and a wide range of applications (primary in pharmaceutical use, food and bioenergetics) started to gain recently more and more attention on a scientific level. Average height of the selected plants was not significantly different at the first measurement before applying CCC, but already after the first week of CCC application applying CCC significant differences were observed between CCC-treated plants and Control (Tab.1).

The difference between the means from the last week measurement of the experiment was $46.1 \mathrm{~cm}$. The weather conditions during vegetative 
Tab. 1. Effects of growth retardant with $0.75 \%$ CCC on Jerusalem artichoke height (Mean and \pm standard deviation presented)

\begin{tabular}{|c|c|c|c|c|c|c|c|c|c|c|c|c|}
\hline \multicolumn{13}{|c|}{ Measurement } \\
\hline $\begin{array}{c}\text { Means } \\
{[\mathrm{cm}]}\end{array}$ & 1 & 2 & 3 & 4 & 5 & 6 & 7 & 8 & 9 & 10 & 11 & 12 \\
\hline $\begin{array}{l}\text { CCC- } \\
\text { treated }\end{array}$ & $\begin{array}{c}52.2 \\
\pm \\
0.5 \mathrm{a}^{*}\end{array}$ & $\begin{array}{c}66.3 \\
\pm \\
0.9 \mathrm{a}\end{array}$ & $\begin{array}{c}74.7 \\
\pm \\
1.8 \mathrm{a}\end{array}$ & $\begin{array}{c}84.3 \\
\pm \\
2.7 \mathrm{a}\end{array}$ & $\begin{array}{c}96.4 \\
\pm \\
3.5 \mathrm{a}\end{array}$ & $\begin{array}{c}114.0 \\
\pm \\
4.7 \mathrm{a}\end{array}$ & $\begin{array}{c}139.0 \\
\pm \\
5.9 \mathrm{a}\end{array}$ & $\begin{array}{c}172.7 \\
\pm \\
8.4 \mathrm{a}\end{array}$ & $\begin{array}{c}199.0 \\
\pm \\
9.8 \mathrm{a}\end{array}$ & $\begin{array}{c}220.2 \\
\pm \\
10.2 \mathrm{a}\end{array}$ & $\begin{array}{c}234.0 \\
\pm \\
10.9\end{array}$ & $\begin{array}{c}244.0 \\
\pm \\
9.3 \mathrm{a}\end{array}$ \\
\hline Control & $\begin{array}{c}52.4 \\
\pm \\
0.3 \mathrm{a} \\
\end{array}$ & $\begin{array}{c}76.0 \\
\pm \\
0.7 \mathrm{~b} \\
\end{array}$ & $\begin{array}{c}93.9 \\
\pm \\
1.6 \mathrm{~b} \\
\end{array}$ & $\begin{array}{c}112.8 \\
\pm \\
2.8 \mathrm{~b} \\
\end{array}$ & $\begin{array}{c}134.6 \\
\pm \\
3.3 \mathrm{~b} \\
\end{array}$ & $\begin{array}{c}157.6 \\
\pm \\
3.3 \mathrm{~b} \\
\end{array}$ & $\begin{array}{c}180.9 \\
\pm \\
4.3 \mathrm{~b} \\
\end{array}$ & $\begin{array}{c}215.6 \\
\pm \\
4.7 \mathrm{~b} \\
\end{array}$ & $\begin{array}{c}239.7 \\
\pm \\
4.3 \mathrm{~b} \\
\end{array}$ & $\begin{array}{c}263.6 \\
\pm \\
6.3 \mathrm{~b}\end{array}$ & $\begin{array}{c}277.7 \\
\pm \\
8.6 \mathrm{~b}\end{array}$ & $\begin{array}{c}290.1 \\
\pm \\
8.6 \mathrm{~b} \\
\end{array}$ \\
\hline
\end{tabular}

*-means followed by the same letters are not significantly different according to HSD test for $\mathrm{p}=0.05$

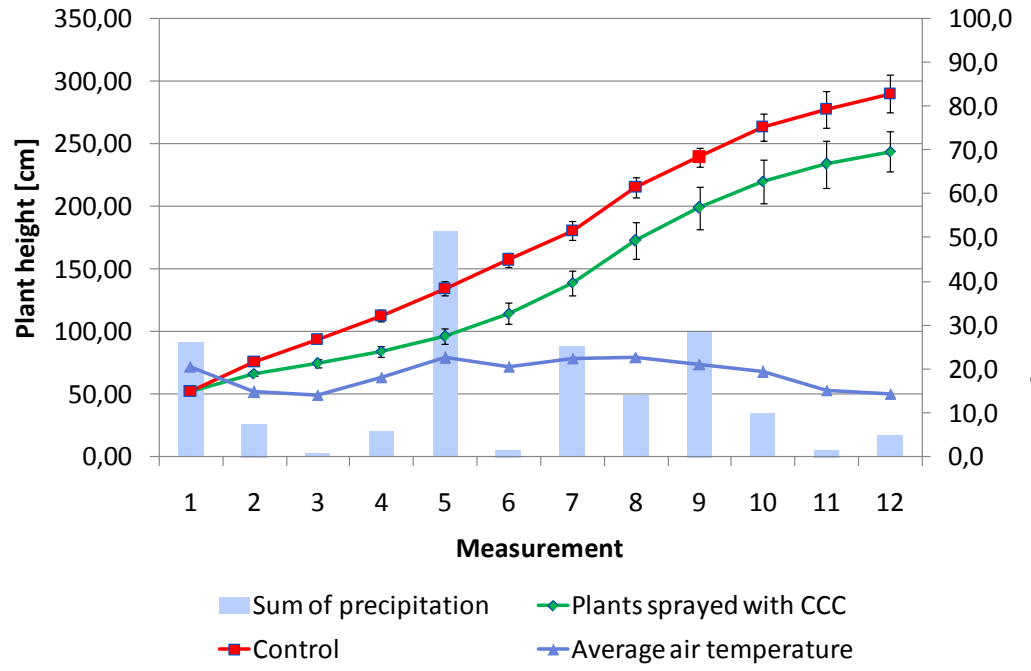

$\rightarrow$ Control $\rightarrow$ Average air temperature

Fig. 2. Effects of the growth retardant $0.75 \%$ CCC on Jerusalem artichoke plants' height. Temperature and precipitation data was provided by the Experimental Station Marcelin.

Tab. 2. Effects of the growth retardant $0.75 \%$ CCC on average weekly growth of plants and height difference between the CCC-treated plants and the Control ones. (Mean and \pm standard deviation presented)

\begin{tabular}{|c|c|c|c|c|c|c|c|c|c|c|c|}
\hline \multicolumn{12}{|c|}{ Measurement } \\
\hline $\begin{array}{l}\text { Weekly } \\
\text { growth } 11 \\
{[\mathrm{~cm}]:}\end{array}$ & 22 & 33 & 44 & 55 & 66 & 77 & 88 & 99 & 110 & 111 & 112 \\
\hline $\begin{array}{c}\text { CCC- } \\
\text {-treated }\end{array}$ & - $114.1 \pm 1.1$ & $88.4 \pm 0.9 a$ & $99.6 \pm 1.0 \mathrm{a}$ & $112.1 \pm 0.9 \mathrm{a}$ & a $118.6 \pm 1.2 \mathrm{a}$ & $224.1 \pm 2.8 \mathrm{a}$ & $333.7 \pm 2.5 \mathrm{a} 2$ & $226.3 \pm 1.6 \mathrm{a} 2$ & $221.2 \pm 2.0 \mathrm{a} 1$ & $113.9 \pm 2.1 \mathrm{a}$ & $99.9 \pm 1.6 \mathrm{a}$ \\
\hline Control & $-223.6 \pm 0.9$ & $117.9 \pm 0.9 \mathrm{~b}$ & $118.9 \pm 1.9 \mathrm{a}$ & $221.8 \pm 2.8 \mathrm{a}$ & a $222.9 \pm 1.8 \mathrm{a}$ & $223.3 \pm 1.9 \mathrm{a}$ & $334.7 \pm 0.5 \mathrm{a} 2$ & $224.1 \pm 1.4 \mathrm{a} 2$ & $223.9 \pm 2.7 \mathrm{a} 1$ & $114.2 \pm 2.8 \mathrm{a}$ & $112.3 \pm 0.3 \mathrm{a}$ \\
\hline $\begin{array}{c}\text { Hight } \\
\text { difference - - }\end{array}$ & $13 \%$ & $20 \%$ & $225 \%$ & $228 \%$ & $227 \%$ & $223 \%$ & $220 \%$ & $117 \%$ & $116 \%$ & $116 \%$ & $116 \%$ \\
\hline
\end{tabular}

season was good and it had favorable the growth of plants (Fig. 2).

Table 2 shows that in the first 4 weeks after application of CCC, the average weekly growth in plants sprayed with CCC was almost two times lower than in the Control plants with significant differences in the second and third week of measurements. However, by time the weekly growth had leveled out. The strongest average growth was recorded in July and early in August (between measurements 8 and 9), reaching the maximum increase of $34.7 \mathrm{~cm}$ in one week of growth for the Control plants and $33.7 \mathrm{~cm}$ for the CCC-treated plants. During the last measurement, 
Tab. 3. Inulin content in $100 \mathrm{~g}$ fresh weight of Jerusalem artichoke tubers (Mean and \pm standard deviation presented)

\begin{tabular}{ccc}
\hline Plants & CCC-treated & Control \\
\hline & 16.06 & 15.60 \\
\cline { 2 - 3 } Inuline [g/100 g] & 16.01 & 15.02 \\
\cline { 2 - 3 } & 15.73 & 15.14 \\
\cline { 2 - 3 } & 15.85 & 15.66 \\
\cline { 2 - 3 } & 14.98 & 15.76 \\
\hline Mean & 14.83 & 15.86 \\
\hline${ }^{*}$ - means followed by the same letters are not significantly different according to the HSD test for $\mathrm{p}=0.05$
\end{tabular}
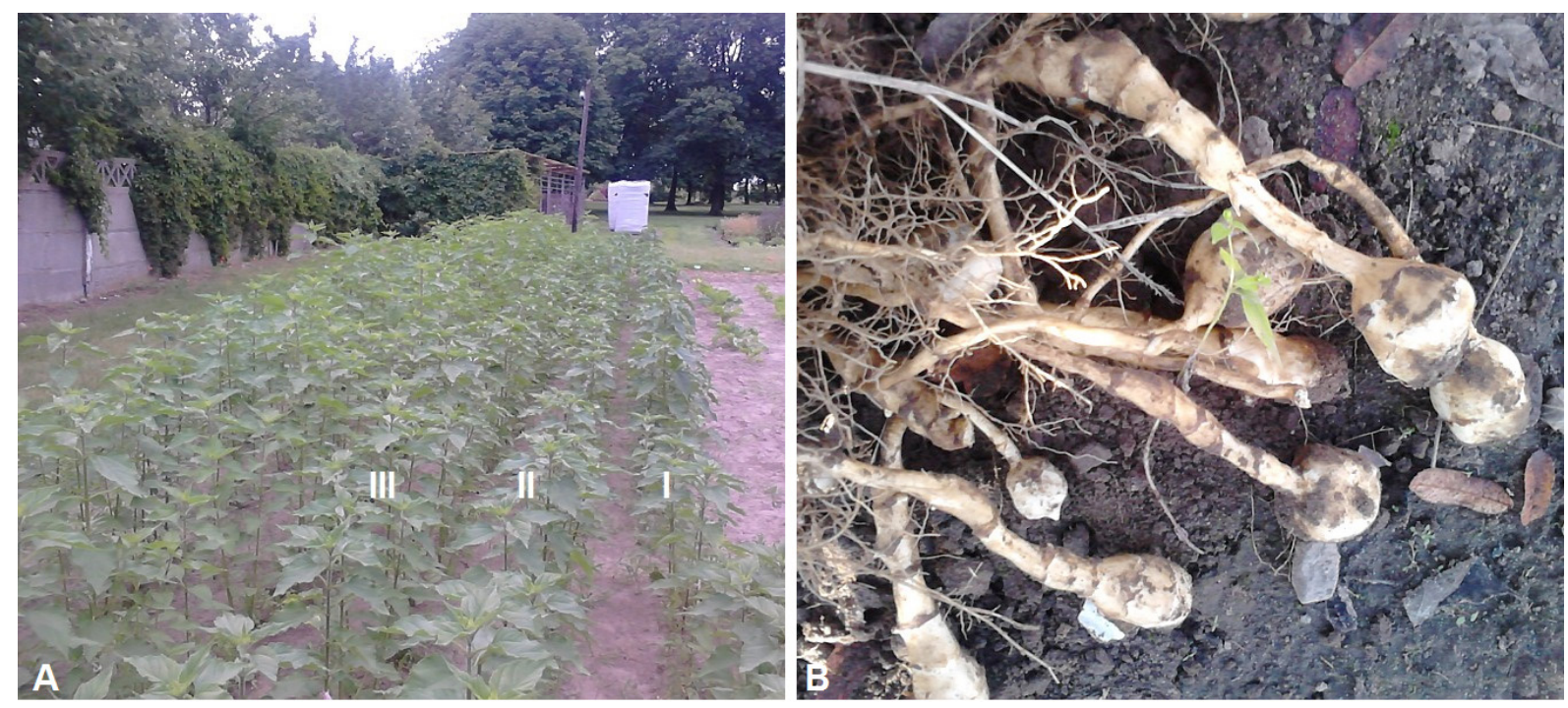

Fig. 3. (A) rows I-III sprayed with $0.75 \%$ CCC two weeks after application. Height differences were already visible; (B) Jerusalem artichoke tubers collected for inulin analysis in November, 2014

the difference between mean height of CCC-treated plant and Control plants was $16 \%$. Differences in weekly growth were observed in first weeks after applying CCC decisive for reducing plants height.

Although, CCC has been used widely growth retardant in Horticulture and Agriculture such as anti-lodging factor for cereals or for height and vertical growth reduction of ornamental plants (Hołubowicz, 1998; Podbukiewicz, 2005), in the available scientific literature there have been no studies carried out on the effects of CCC on plants' growth and height of Jerusalem artichoke. It is also known that effectively reduce plants' height of sunflower-Helianthus annuus L. (Jones and Phillips, 1967).

The percentage of inulin in $100 \mathrm{~g}$ of each picked tuber (Fig. 3 B) was examined and compared for both the CCC-treated plants and the control ones.
The results are shown in Tab. 3. The analyses made showed no significant differences in the inulin content of the tubers. The inulin content was approx. $16 \%$, which according to the scientific literature is specific value for this species (Van Loo et al., 1995). CCC at this concentration is safe to use as growth inhibitor agent, causing no loss in sugar content in the plants' tubers.

In our study using a $0.75 \%$ CCC in the trade product called "Antywylegacz" had resulted in effective plant growth inhibition and it was achieved already after the first week of retardant application (Fig. 3 A). During our research we managed to reduce the height of the plants on average $16 \%$ compared to the Control ones. The used concentration and type of active ingredient used in the experiment had a positive impact on reducing plants' height. 


\section{CONCLUSIONS}

1) The use of the trade growth retardant under the trade name "Antywylegacz" containing CCC, at a concentration of $0.75 \%$, reduced the plants' height in all of the plants after treatment. Their average height decreased by $16 \%$ compared to the unsprayed, Control plants.

2) The applied retardant had no effect on the inulin content of Jerusalem artichoke tubers.

3) The trade growth retardant "Antywylegacz" containing CCC had a great efficiency in plant height reduction of Jerusalem artichoke plants.

\section{REFERENCES}

1. Ahmed MS, El-Sakhawy FS, Soliman SN, Abou HDMR (2005). Phytochemical and biological study of Helianthus tuberosus. Egypt. J. Biomed. Sci. 28:134-147.

2. Barclay T, Ginic-Markovic M, Cooper P, Petrovsky N (2010). Inulin - a versatile polysascharide with multiple pharmaceutical and food chemical uses. J Exc Food Chem 3:27-50.

3. Cosgrove DR, Oelke EA, Doll JD, Davis DW, Undersander DJ, Oplinger ES (1991). Jerusalem Artichoke w Alternative Field Crops Manual, http://www.hort.purdue.edu/ newcrop /afcm/jerusart.html.

4. D’Edigio MG, Cechini C, Cervigni T, Donini B, Pignatelli V. (1998). Production of fructose from cereal stems and polyannual cultures of Jerusalem artichoke. Ind. Crops and Prod. 7:113-119.

5. Duke JA (1983). Handbook of energy crops. Available at: www.hort.purdue.edu/newcrop/ duke_energy/ Helianthus_tuberosus.html.

6. Gaafar AM, Serag El-Din MF, Boudy EA, El-Gazar HH (2010). Extraction conditions of inulin from Jerusalem artichoke tubers and its effects on blood glucose and lipid profile in diabetic rats. J. Amer. Sci., 6(5): 36-43.

7. Gunnarsson IB, Svensson SE, Johansson E, Karakashev D, Angelidaki I (2014). Potential of Jerusalem artichoke
(Helianthus tuberosus L.) as a biorefinery crop. Ind Crops Prod. 56:231-240.

8. Hołubowicz R (1998). Effect of growth regulators on seed stalks growth and seed production of onion, leek, garden carrot and lettuce. Rocz. AR - Poznań, Rozp. Nauk. 280:1113

9. Jones RL, Phillips J (1967). Effect of CCC on the gibberellins content of excised sunflower organs. Planta (Berl.) 72:5359.

10. Matias J, Gonzalez J, Cabanillas J, Royano L (2013). Influence of NPK fertilization and harvest date on agronomic performance of Jerusalem artichoke crop in the Guadiana Basin (Southwestern Spain). Ind. Crops Prod 48:191-197.

11. Pobudkiewicz A (2005). Retardants, i.e. compounds to improve plants' growth habit. Hasło Ogr. 3/2005.

12. Rademacher W (2000). Growth Retardants: Effects on Gibberellin Biosynthesis and Other Metabolic Pathways. Ann. Rev. Plant Phys Mol Biol51:501-531.

13. Radwan A, El-Fouly M, Garas NA (1971). Retarding stem elongation and stimulating dry matter production and yield of potato with chlormequat chloride (CCC). J Pot Res 14:173-180.

14. Ramnani P, Gaudier E, Bingham M, van Bruggen P, Tuohy KM, Gibson GR (2010). Prebiotic effect-of fruit and vegetable shots containing Jerusalem artichoke inulin: a human intervention study. Brit J Nutr 104: 233-240.

15. Van Loo J, Coussement P, de Leenheer, L, Hoebregs H, Smits G (1995). On the presence of inulin and oligofructose as natural ingredients in the western diet. Crit Rev Food Sci Nut 35(6):525-552.

16. Xiao YM, Li HZ, Hong BS, Gang X, Feng Z, Fu TN, Brestic M (2011). Jerusalem artichoke (Helianthus tuberosus L.), a medical salt resistant plant has high adaptability and multiple-use values. J Med Plants Res 5(8):1272-1279.

17. Zhao GM, Liu ZP, Chen MD, Guo SW (2008). Soil properties and yield of Jerusalem artichoke (Helianthus tuberosus L.) with seawater irrigation in North China Plain. Pedosphere, 18:195-134. 